\title{
EFFECT OF SALINITY AND HUMIC ACID TREATMENTS ON GROWTH AND CHEMICAL COMPOSITION OF Jatropha curcas PLANTS
}

\author{
(Received : 7. 9. 2014)
}

\author{
By \\ N. A. El-Shanhorey, M. Z.M. Salem* and N. H. Mohamed ${ }^{* *}$ \\ Botanical Gardens Research Department, Horticultural Research Institute, \\ Agriculture Research Center, Alexandria, Egypt. \\ * Forestry and Wood Technology Department, Faculty of Agriculture (EL-Shatby), \\ Alexandria University, Alexandria, Egypt. \\ ** Timber Trees Research Department, Horticultural Research Institute, \\ Agriculture Research Center, Alexandria, Egypt.
}

\begin{abstract}
This investigation was carried out at Antoniades Research Branch, Horticulture Institute, Ministry of Agriculture, Alexandria, Egypt during 2012 and 2013 seasons. The study was a trial to investigate the effect of different levels of salinity $(0,3000,6000$ and $9000 \mathrm{ppm})$ and different concentrations of humic acid sprayed on the leaves $(0,500,1000$ and $1500 \mathrm{ppm})$ and their combinations on the vegetative growth and some chemical constituents of Jatropha curcas plants grown in plastic pots 30 $\mathrm{cm}$ filled with sandy soil.

The results revealed that the irrigation salinity level was more effective than humic acid concentrations on all the studied characteristics of Jatropha curcas plant. Additionally, using tap water (control) combined with humic acid at $1000 \mathrm{ppm}$ gave the highest significant values of plant height, stem diameter, stem dry weight, leaf number, leaf dry weight, leaf area, root length, root dry weight, chlorophyll, proline and carbohydrate contents of the leaves.

Generally, the results obtained recommend irrigating the cultivated plants in the sandy soil three times per week using irrigation water with salinity level not more than $6000 \mathrm{ppm}$ combined with humic acid at the rate of $1000 \mathrm{ppm}$ gave good improvements in the vegetative growth and some chemical constituents of Jatropha curcas plants grown in sandy soil.
\end{abstract}

Key words: Jatropha curcas, saline irrigation water, humic acid.

\section{INTRODUCTION}

Jatropha curcas is a species of flowering plants in the spurge family, Euphorbiaceae, that is native of the American tropics, most likely Mexico and central America (Janick and Robort, 2008). Jatropha curcas grows in tropical and subtropical regions. The plant can grow in wastelands and grow on almost any terrain, even on gravelly, sandy and saline soils. Complete germination is achieved after 9 days. Jatropha curcas starts yielding after $9-12$ months, the best yield is obtained only after $2-3$ years (Juhasz et al., 2009).

Salinity is one of the major environmental factors determining plant productivity and plant distribution. Salinity affects more than $10 \%$ of Arab lands. In general, desertification and salinization are rapidly increasing on a global scale, leading to declining the average yields of most major crop plants. Several researchers have reported that water salinity also has considerable effect on the growth of different ornamental tree species (Sapeta et al., 2013).

Jatropha curcas are known to be relatively tolerant to salinity (Genhua et al., 2012). However, significant reduction in vegetative growth characteristics is expected to occur if the salinity level is increased above a certain critical level. This study was conducted with the aim of investigating the effect of different irrigation water salinity levels on the growth and chemical costituents of Jatropha curcas, and to assess the possibility of using humic acid treatments to overcome the adverse effects of salinity on plant growth. 


\section{MATERIALS AND METHODS}

The present study was carried out at Antoniades Research Branch, Horticulture Research Institute, A.R.C. Alexandria, Egypt during the two successive seasons of 2012 and 2013.

On the $15^{\text {th }}$ of March, 2012 and 2013 (in the first and second seasons, respectively) transplants of Jatropha curcas $(30 \mathrm{~cm}$ tall) were planted individually in plastic pots $(30 \mathrm{~cm}$ diameter) filled with $10 \mathrm{~kg}$ of sandy soil. The chemical constituents of the soil were measured as described by Jackson (1958)and shown in Table (1). On the $15^{\text {th }}$ of April (in both seasons), the saline irrigation water treatments were initiated, the different saline water concentrations were prepared, using sodium chloride $(\mathrm{NaCl})$. The plants were irrigated three times per week using saline water concentrations
- Carbohydrate contents of the leaves were determined according to Dubios et al. (1956) .

- Sodium and chloride contents (\% of dry matter) in the leaves were determined according to Piper (1947).

- Relative Water Contents of leaves (\%) in the fresh leaves were determined according to Barrs (1968) and Ritche (1974).

- Proline content $(\mathrm{mg} / \mathrm{g})$ in the leaves was determined according to Bates et al. (1973).

The layout of the experimental design was split plot with three replicates. Each replicate contained three plants. The main plots were the salinity levels while the sup plots were the concentrations of humic acid. The means of the individual factors and their interactions were compared by L.S.D test at 5\% level of probability according to Snedecor and Cochran (1974).

Table (1): Some chemical analysis of the used sandy soil for the two successive seasons 2012 and 2013.

\begin{tabular}{|c|c|c|c|c|c|c|c|c|c|}
\hline \multirow[t]{2}{*}{ Season } & \multirow[t]{2}{*}{ pH } & \multirow{2}{*}{$\begin{array}{c}E C \\
\left(d_{S_{m}}^{-1}\right)\end{array}$} & \multicolumn{4}{|c|}{ Soluble cations (mg/l) } & \multicolumn{3}{|c|}{ Soluble anions (mg/l) } \\
\hline & & & $\mathbf{C a}^{++}$ & $\mathbf{M g}^{++}$ & $\mathrm{Na}^{+}$ & $\mathbf{K}^{+}$ & $\mathrm{HCO}_{3}^{-}$ & $\mathrm{Cl}^{-}$ & $\mathrm{SO}_{2}$ \\
\hline 2012 & 7.87 & 1.51 & 3.1 & 4.2 & 6.4 & 1.1 & 3.5 & 6.5 & 2.4 \\
\hline 2013 & 7.92 & 1.43 & 3.4 & 2.9 & 6.2 & 0.9 & 3.2 & 6.3 & 2.1 \\
\hline
\end{tabular}

of tap water (control), 3000, 6000 and 9000 ppm. In both seasons, the plants received the salinity levels by monthly from 15 May till 15 August in both seasons. The plants were also sprayed with humic acid at concentrations of 0 , 500, 1000 and $1500 \mathrm{ppm}$. Control plants were sprayed with tap water. on the $15^{\text {th }}$ of September (in both seasons).

In both seasons, all plants received NPK chemical fertilization using fertilizer (Milagro Aminoleaf 20-20-20) at the rate of $3 \mathrm{~g} /$ pot. Fertilization was repeated every 30 days throughout the growing season (from the $20^{\text {th }}$ of April till the $15^{\text {th }}$ of August). In addition, weeds were removed manually upon emergence.

\subsection{Data recorded}

2.1.1. Vegetative growth parameters: Plant height $(\mathrm{cm})$, leaf number per plant, leaf area $\left(\mathrm{cm}^{2}\right)$, leaf dry weight per plant $(\mathrm{g})$, stem diameter $(\mathrm{cm})$, stem dry weight $(\mathrm{g})$, root length $(\mathrm{cm})$ and root dry weight $(\mathrm{g})$.

\subsubsection{Chemical analysis determination}

-Chlorophyll contents were determined as SPAD unites of the fresh leaves of plants for the different treatments of the experiment at the end of the season using Minolta (chlorophyll meter) SPAD 502 according to Yadava (1986).

\section{RESULTS AND DISCUSSION \\ 3.1.Vegetative growth \\ 3.1.1. Plant height $(\mathrm{cm})$}

Data presented in Table (2a) show that in both seasons, irrigation with saline water decreased the height of Jatropha curcas plants, compared to the plants irrigated with tap water (control). Plants irrigated with tap water had the highest mean values of plant height 38.62 and $42.02 \mathrm{~cm}$ in the first and the second seasons, respectively. Moreover, raising the salt concentration caused steady significant reductions in plant height, with the highest concentration $(9000 \mathrm{ppm})$ giving the shortest plants significantly (with mean heights of 27.12 and $30.95 \mathrm{~cm}$ in the two seasons, respectively) than those receiving any other salt concentration. Similar results were reported by Abd El-Aziz et al. (2006) on Khaya senegalensis, El- Juhany et al. (2008) on Eucalyptus camaldulensis, Eucalyptus intertexta and Eucalyptus microtheca, and Sharif and Khan (2009) on Salvadora oleoides, Prosopis cineraria, Capparis decidue and Tamarix aphylla. The reduction in plant height as a result of high salt concentration was explained by Yasseen et al. (1987) and St. Arnaud and Vincent (1990), where they mentioned that the decrease in plant height under saline conditions was probably due 
to the insufficient uptake of water and nutrients, as well as sodic toxicity.

Plant height was also significantly affected by spraying the plants with humic acid. In both seasons, plant height increased gradually when the humic acid concentration was raised from 0 ppm (control) to $1000 \mathrm{ppm}$. However, a further increase in humic acid concentration from 1000 ppm to $1500 \mathrm{ppm}$ resulted in a gradual decrease in plant height. Accordingly, it can be seen from the data in Table (2a) that Jatropha curcas plants sprayed with 1000 ppm humic acid were significantly taller (with mean plant heights of 34.91 and $38.50 \mathrm{~cm}$ in the first and second seasons, respectively) than plants sprayed with any other humic acid concentration. The increase in height of Jatropha curcas plants as a result of spraying with humic acid is similar to the increases in height that had been recorded on other ornamental plant species, by El-Khateeb et al. (2010) on Calia secundiflora, Cavalcante et al. (2011) on Carica papaya.

Regarding the interaction between the effects of irrigation water salinity and humic acid treatments on growth rate of the plant height of Jatropha curcas plants, the results recorded in the two seasons show that, the highest values were obtained in the plants irrigated with tap water and sprayed with humic acid at $1000 \mathrm{ppm}$ (with mean heights of 41.00 and $44.25 \mathrm{~cm}$ in the first and second seasons, respectively). On the other hand, the shortest plants (with mean

Table (2-a): Means of vegetative growth characteristics of Jatropha curcas plants as influenced by Salinity (S), Humic acid (HA) and their combinations (S× HA) in the two seasons of 2012 and 2013.

\begin{tabular}{|c|c|c|c|c|c|c|c|}
\hline \multicolumn{2}{|c|}{ Treatments } & \multicolumn{2}{|c|}{ Plant height $(\mathrm{cm})$} & \multicolumn{2}{|c|}{$\begin{array}{c}\text { Number of leaves } \\
\text { per plant }\end{array}$} & \multicolumn{2}{|c|}{$\begin{array}{c}\text { Leaves dry weight }(\mathrm{g}) \\
\text { per plant }\end{array}$} \\
\hline $\begin{array}{l}\text { Salinity } \\
\text { (ppm) }\end{array}$ & $\begin{array}{c}\text { Humic acid } \\
\text { (ppm) }\end{array}$ & 2012 & 2013 & 2012 & 2013 & 2012 & 2013 \\
\hline \multirow{4}{*}{0} & 0 & 35.00 & 38.41 & 23.33 & 25.83 & 36.08 & 38.39 \\
\hline & 500 & 39.50 & 42.91 & 26.33 & 28.83 & 41.38 & 43.43 \\
\hline & 1000 & 41.00 & 44.25 & 27.33 & 29.33 & 43.12 & 44.27 \\
\hline & 1500 & 39.00 & 42.50 & 26.60 & 28.33 & 40.80 & 42.59 \\
\hline \multicolumn{2}{|l|}{ Mean } & 38.62 & 42.02 & 25.75 & 28.08 & 40.35 & 42.17 \\
\hline \multirow{4}{*}{3000} & 0 & 30.75 & 33.75 & 20.50 & 22.50 & 31.09 & 32.79 \\
\hline & 500 & 34.00 & 37.00 & 22.66 & 24.66 & 34.92 & 36.43 \\
\hline & 1000 & 36.41 & 40.00 & 24.33 & 26.66 & 37.88 & 39.79 \\
\hline & 1500 & 33.25 & 36.75 & 22.16 & 24.50 & 34.05 & 36.15 \\
\hline \multicolumn{2}{|l|}{ Mean } & 33.60 & 36.87 & 22.41 & 24.58 & 34.48 & 36.29 \\
\hline \multirow{4}{*}{6000} & 0 & 27.25 & 30.83 & 18.16 & 20.50 & 27.01 & 29.44 \\
\hline & 500 & 31.00 & 34.50 & 20.66 & 23.00 & 31.41 & 33.64 \\
\hline & 1000 & 32.75 & 36.41 & 21.83 & 24.16 & 33.47 & 35.60 \\
\hline & 1500 & 31.00 & 34.83 & 20.66 & 23.16 & 31.45 & 33.92 \\
\hline \multicolumn{2}{|l|}{ Mean } & 30.50 & 34.14 & 20.33 & 22.70 & 30.83 & 33.15 \\
\hline \multirow{4}{*}{9000} & 0 & 23.75 & 27.00 & 15.83 & 18.00 & 22.88 & 25.23 \\
\hline & 500 & 27.00 & 31.25 & 18.00 & 20.83 & 26.76 & 30.00 \\
\hline & 1000 & 29.50 & 33.33 & 19.66 & 22.16 & 29.65 & 32.24 \\
\hline & 1500 & 28.25 & 32.25 & 18.83 & 21.50 & 28.19 & 31.11 \\
\hline \multicolumn{2}{|l|}{ Mean } & 27.12 & 30.95 & 18.08 & 20.62 & 26.87 & 29.64 \\
\hline \multirow{4}{*}{ Mean (HA) } & 0 & 29.18 & 32.50 & 19.45 & 21.70 & 29.26 & 31.46 \\
\hline & 500 & 32.87 & 36.41 & 21.91 & 24.33 & 33.62 & 35.87 \\
\hline & 1000 & 34.91 & 38.50 & 23.29 & 25.58 & 36.03 & 37.97 \\
\hline & 1500 & 32.87 & 36.58 & 21.91 & 24.37 & 33.62 & 35.94 \\
\hline \multirow{3}{*}{ L.S.D. at 0.05} & $\mathbf{S}$ & 1.94 & 1.40 & 1.28 & 0.88 & 2.11 & 1.42 \\
\hline & H A & 0.70 & 0.60 & 0.46 & 0.36 & 0.84 & 0.60 \\
\hline & $\mathbf{S} \times \mathbf{H A}$ & 2.27 & 1.73 & 1.51 & 1.07 & 2.55 & 1.76 \\
\hline
\end{tabular}


heights of 23.75 and $27.00 \mathrm{~cm}$ in the first and second seasons, respectively) resulted in the plants irrigated using the highest salt concentration (9000 ppm) without humic acid treatment. It can also be seen from the data presented in Table (2a) that in many cases, spraying the plants with humic acid reduced the undesirable effect of salinity. Similar results were reported by Abd El-Aziz et al. (2006) on Khaya senegalensis, Sayed (2006) on Ficus alii, El-Juhany et al. (2008) on Eucalyptus camaldulensis, Eucalyptus intertexta and Eucalyptus microtheca and Sharif and Khan (2009) on Salvadora oleoides, Prosopis cineria, Capparis decidue and Tamarix aphylla.

\subsubsection{Number of leaves per plant}

The data presented in Table (2a) show the effect of saline water on the number of leaves formed on Jatropha curcas plants. In both seasons, plants irrigated with tap water had the highest number of leaves 25.75 and 28.08 leaves/plant in the first and second seasons, respectively. Accordingly, the lowest number of leaves 18.08 and 20.62 leaves / plant in the first and second seasons, respectively, was formed by plants that were irrigated using the highest salt concentration $(9000 \mathrm{ppm})$. Similar results were reported by El-Juhany and Aref (2005) on Conocarpus erectus, Abd EI-Aziz et al. (2006) on Khaya senegalensis and El-Juhany et al. (2008) on Eucalyptus camaldulensis, Eucalyptus intertexta and Eucalyptus microtheca.

Concerning the effect of humic acid treatments on the number of leaves, the data recorded in the two seasons (Table 2a) show that humic acid treatment at $1000 \mathrm{ppm}$ caused a significant increase in the number of leaves giving mean values of 23.29 and $25.58 \mathrm{gm} / \mathrm{plant}$ in the first and second seasons, respectively, compared to that of the control plants (19.45 and $21.70 \mathrm{~g} /$ plant in the two seasons, respectively). The increase in the number of leaves of plants sprayed with humic acid at 1000 ppm supports the results reported by Fathy et al. (2010) on Prunus armeniaca and El-Khateeb et al. (2010) on Calia secundiflora.

The data in Table (2a) show that, significant interaction was detected in both seasons between the effects of irrigation water salinity and humic acid treatments on the number of leaves formed by Jatropha curcas plants. Combining irrigation using tap water with spraying the plants with humic acid at $1000 \mathrm{ppm}$ gave the highest number of leaves ( 27.33 and 29.33) per plant in the first and second seasons, respectively. On the other hand, the least number of leaves per plant was recorded in the first season 15.83 and 18.00 leaves per plant in the first and second seasons, respectively. These were obtained on plants irrigated using the highest salt concentration (9000 ppm) and sprayed without any humic acid concentration. Similar results were reported by El-Juhany and Aref (2005) on Conocarpus erectus, Abd El-Aziz et al. (2006) on Khaya senegalensis, Sayed (2006) on Ficus alii and ElJuhany et al. (2008) on Eucalyptus camaldulensis, Eucalyptus intertexta and Eucalyptus microtheca.

\subsubsection{Leaf dry weight (g) per plant}

The results recorded in the two seasons (Table 2a) show that the heaviest dry weights of leaves $40.35 \mathrm{~g}$ and $42.17 \mathrm{~g}$ in the first and second seasons, respectively, were obtained from plants irrigated with tap water. Irrigation with water containing any salt concentration decreased the dry weight of the leaves significantly. Moreover, the recorded values decreased steadily with raising the salt concentration. Accordingly, the least values 26.87 and $29.64 \mathrm{~g} /$ plant in the first and second seasons, respectively, were obtained from plants irrigated with the highest salt concentration (9000 ppm). This reduction in the dry weight of leaves as a result of salinity treatments is similar to that obtained by El-Juhany and Aref (2005) on Conocarpus erectus, and Abd El-Aziz et al. (2006) on Khaya senegalensis.

The data presented in Table (2a) also show that spraying Jatropha curcas plants with humic acid at $1000 \mathrm{ppm}$ significantly increased the dry weight of the leaves giving values of 36.03 and $37.97 \mathrm{~g} / \mathrm{plant}$ in the first and second seasons, respectively, compared to the control (29.26 and $31.46 \mathrm{~g} / \mathrm{plant}$ in the first and second seasons, respectively).

Regarding the interaction between the effects of irrigation with saline water and humic acid treatments on the dry weight of the leaves of Jatropha curcas, the data presented in Table (2a) showed that the heaviest dry weights of leaves of $43.12 \mathrm{gm}$ and $44.27 \mathrm{~g}$ in the first and second seasons, respectively, were obtained in plants irrigated with tap water and sprayed with humic acid at $1000 \mathrm{ppm}$, whereas the lowest dry weights of leaves of 22.88 and $25.23 \mathrm{~g}$ in the first and second seasons, respectively, were obtained when the plants were irrigated using the highest salt concentration $9000 \mathrm{ppm}$ without any humic acid treatment.This reduction in the dry weight of leaves as a result of salinity treatments 
is similar to that obtained by El-Juhany and Aref (2005) on Conocarpus erectus, Abd El-Aziz et al. (2006) on Khaya senegalensis and Sayed (2006) on Ficus alii.

\subsubsection{Leaf area $\left(\mathrm{cm}^{2}\right)$}

The results recorded in the two seasons (Table 2b) show that irrigation with saline water decreased the leaf area of Jatropha curcas plants, compared to the plants irrigated with tap water (control). In both seasons, plants irrigated with tap water (control) had the largest leaves with mean areas of 2591.17 and $2822.90 \mathrm{~cm}^{2}$ in the first and second seasons, respectively. The leaf area was decreased steadily with raising the salt concentration. Accordingly, the smallest leaves with mean areas of 655.32 and 721.63 $\mathrm{cm}^{2}$ in the first and second seasons, respectively, were those formed on plants that were irrigated using the highest salt concentration $9000 \mathrm{ppm}$. Similar results were reported by Awan et al. (2002a) on Eucalyptus camaldulensis, and Awan et al. (2002b) on Dalbergia sisoo.

The data presented in Table (2b) show that, the different humic acid treatments had a significant effect on leaf area of Jatropha curcas plants. Plants sprayed using humic acid at 1000 ppm formed significantly larger leaves (with a mean area of 1798.76 and $1938.79 \mathrm{~cm}^{2}$ in the first and second seasons, respectively, than those formed by control plants (1115.18 and $1229.88 \mathrm{~cm}^{2}$ ), Similar increases in leaf area as a result of humic acid treatments have been reported by Fathy et al. (2010) on Prunus armeniaca.

The data presented in Table (2b) also show that significant interaction was detected between the effects of irrigation water salinity and humic acid treatments on the area of Jatropha curcas leaves. In the first seasons, the largest leaves with mean areas of $2850.86 \mathrm{~cm}^{2}$ were formed by plants irrigated with tap water and sprayed with humic acid at $1000 \mathrm{ppm}$, In the second season, the largest mean areas $3089.66 \mathrm{~cm}^{2}$ were formed by plants irrigated with tap water and sprayed with humic acid at $1500 \mathrm{ppm}$. On the other hand, the smallest leaves (with areas of 505.80 and $585.41 \mathrm{~cm}^{2}$ in the first and second seasons, respectively) were obtained on plants irrigated using the highest salt concentration $(9000 \mathrm{ppm})$ combined with the lowest concentration $500 \mathrm{ppm}$ humic acid treatment. Similar results were reported by Awan et al. (2002a) on Eucalyptus camaldulensis, and Awan et al. (2002b) on Dalbergia sissoo.

It can also be seen that in many cases, the humic acid treatments counteracted (at least partly) the adverse effect of the salinity treatments on leaf area. For example, in plants that were irrigated using the highest salt concentration (9000 ppm), a steady increase in leaf area was recorded as the humic acid concentration was gradually raised, i.e. in both seasons, plants that were irrigated with saline water at $9000 \mathrm{ppm}$ and sprayed with humic acid gave larger leaves than plants receiving the same salinity treatment, but without humic acid.

\subsubsection{Stem diameter $(\mathbf{c m})$}

The data recorded on the stem diameter of Jatropha curcas plants in the two seasons (Table 2b) show that irrigation with saline water decreased stem thickness, compared to that of plants irrigated with tap water (control). In both seasons, plants irrigated with tap water had the thickest stems, with mean diameters of 3.78 and $4.19 \mathrm{~cm}$ in the first and second seasons, respectively. Raising the salt concentration in irrigation water caused a steady reduction in stem diameter. This reduction in stem diameter was significant (compared to the control), even at the highest salt concentration $(9000 \mathrm{ppm})$, which gave stem diameters of 2.69 and $3.10 \mathrm{~cm}$ in the first and second seasons, respectively. Similar results were reported by Abd El-Aziz et al. (2006) on Khaya senegalensis.

In contrast to the effect of salinity treatments, humic acid treatments improved stem diameter of Jatropha curcas plants, compared to the control. Moreover, plants sprayed with 1000 ppm humic acid significantly affected thickest stems (with mean diameters of 3.45 and $3.79 \mathrm{~cm}$ in the first and second seasons, respectively), compared to the those of control plants, or plants sprayed with any other humic acid concentration. Similar increases in stem diameter had been reported by El-Khateeb et al. (2010) on Calia secundiflora and Fathy et al. (2010) on Prunus armeniaca.

Regarding the interaction between the effects of irrigation water salinity and humic acid treatments on growth rate of the stem diameter of Jatropha curcas plants, the results recorded in the two seasons (Table 2 b) show that significant differences were detected between the values obtained from plants receiving the different treatment combinations. The highest values (4.01 and $4.37 \mathrm{~cm}$ in the first and second seasons, respectively) were obtained in the plants irrigated with tap water and sprayed with humic acid at $1000 \mathrm{ppm}$. On the other hand, the thinnest stems (with diameters of 2.35 and 2.67 
$\mathrm{cm}$ in the first and second seasons, respectively) were obtained in the plants irrigated using the highest salt concentration (9000 ppm) without humic acid treatment. It can also be seen that in some cases, the humic acid treatments helped to overcome the adverse effect of the salinity treatments on stem thickening. Similar results were reported by El-Bagoury et al. (1999) on Casuarina equisetifolia, Gu-Zuliang et al. (2002) on Navel Orange and Abd El-Aziz et al. (2006) on Khaya senegalensis.

\subsubsection{Stem dry weight (g)}

Data presented in Table (2b) show that, in both seasons, irrigation with saline water significantly decreased dry weights of stem of Jatropha curcas plants, compared to plants irrigated with tap water (control). Plants irrigated with tap water had the heaviest mean dry weight of stems 45.40 and $50.41 \mathrm{gm}$ per plant in the first and second seasons, respectively. The dry weight of stems showed a gradual reduction as the salt concentration was increased. Accordingly, the least dry weights of stem 32.66 and $37.23 \mathrm{gm}$ per plant in the first and second seasons, respectively, were recorded in plants receiving the highest salt concentration 9000 ppm. These results are in agreement with the fmdings of Aslam et al.(2002) on Eucalyptus camaldulensis, Franklin et al. (2002) on jack pine Pinus banksiana, Gupta et al. (2002) on Ziziphus rotundifolia and Z. nummularia, ElFeky (2004) on Erythrina indica and Tecoma stans, and Abd El-Aziz et al. (2006) on Khaya senegalensis.

Table (2b): Means of vegetative growth characteristics of Jatropha curcas plants as influenced by Salinity (S), Humic acid (HA) and their combinations (S× HA) in the two seasons of 2012 and 2013.

\begin{tabular}{|c|c|c|c|c|c|c|c|}
\hline \multicolumn{2}{|c|}{ Treatments } & \multicolumn{2}{|c|}{ Leaves area $\left(\mathrm{cm}^{2}\right)$} & \multicolumn{2}{|c|}{ Stem diameter $(\mathrm{cm})$} & \multicolumn{2}{|c|}{ Stem dry weight (g) } \\
\hline $\begin{array}{l}\text { Salinity } \\
\text { (ppm) }\end{array}$ & $\begin{array}{c}\text { Humic acid } \\
(\text { ppm) }\end{array}$ & 2012 & 2013 & 2012 & 2013 & 2012 & 2013 \\
\hline \multirow{4}{*}{0} & 0 & 2342.60 & 2552.83 & 3.49 & 3.88 & 41.88 & 46.60 \\
\hline & 500 & 2380.53 & 2606.29 & 3.79 & 4.27 & 45.45 & 51.36 \\
\hline & 1000 & 2850.86 & 3042.80 & 4.01 & 4.37 & 48.20 & 52.52 \\
\hline & 1500 & 2790.66 & 3089.66 & 3.84 & 4.26 & 46.07 & 51.18 \\
\hline \multicolumn{2}{|l|}{ Mean } & 2591.17 & 2822.90 & 3.78 & 4.19 & 45.40 & 50.41 \\
\hline \multirow{4}{*}{3000} & 0 & 912.25 & 1001.25 & 3.05 & 3.35 & 36.65 & 40.26 \\
\hline & 500 & 1482.40 & 1613.20 & 3.34 & 3.60 & 40.14 & 43.34 \\
\hline & 1000 & 1888.26 & 2069.33 & 3.62 & 3.88 & 43.47 & 46.58 \\
\hline & 1500 & 979.76 & 1082.90 & 3.48 & 3.74 & 41.88 & 44.98 \\
\hline \multicolumn{2}{|l|}{ Mean } & 1315.67 & 1441.67 & 3.37 & 3.64 & 40.53 & 43.79 \\
\hline \multirow{4}{*}{6000} & 0 & 648.55 & 731.85 & 2.70 & 3.05 & 32.50 & 36.64 \\
\hline & 500 & 1122.20 & 1248.90 & 3.04 & 3.38 & 36.61 & 40.66 \\
\hline & 1000 & 1421.35 & 1573.25 & 3.25 & 3.58 & 39.10 & 43.08 \\
\hline & 1500 & 739.86 & 829.36 & 3.11 & 3.51 & 37.42 & 42.20 \\
\hline \multicolumn{2}{|l|}{ Mean } & 982.99 & 1095.84 & 3.02 & 3.38 & 36.41 & 40.64 \\
\hline \multirow{4}{*}{9000} & 0 & 557.33 & 633.60 & 2.35 & 2.67 & 28.23 & 32.16 \\
\hline & 500 & 505.80 & 585.41 & 2.67 & 3.08 & 32.35 & 37.02 \\
\hline & 1000 & 1034.56 & 1069.78 & 2.91 & 3.33 & 35.01 & 39.98 \\
\hline & 1500 & 523.56 & 597.70 & 2.83 & 3.31 & 35.07 & 39.76 \\
\hline \multicolumn{2}{|l|}{ Mean } & 655.32 & 721.63 & 2.69 & 3.10 & 32.66 & 37.23 \\
\hline \multirow{4}{*}{ Mean (HA) } & 0 & 1115.18 & 1229.88 & 2.89 & 3.24 & 34.82 & 38.91 \\
\hline & 500 & 1372.73 & 1513.45 & 3.21 & 3.58 & 38.63 & 43.09 \\
\hline & 1000 & 1798.76 & 1938.79 & 3.45 & 3.79 & 41.44 & 45.54 \\
\hline & 1500 & 1258.47 & 1399.91 & 3.31 & 3.70 & 40.11 & 44.53 \\
\hline \multirow{3}{*}{ L.S.D. at 0.05} & $\mathbf{S}$ & 73.53 & 64.78 & 0.15 & 0.16 & 1.56 & 1.94 \\
\hline & HA & 21.47 & 20.89 & 0.07 & 0.05 & 0.93 & 0.70 \\
\hline & $\mathbf{S} \times \mathbf{H A}$ & 81.93 & 73.76 & 0.19 & 0.18 & 2.23 & 2.94 \\
\hline
\end{tabular}


The results recorded in the two seasons (Table $2 b$ ) show that, in both seasons, spraying the plants with humic acid increased the dry weight of the stem. In both seasons, spraying plants with $1000 \mathrm{ppm}$ humic acid gave the heaviest dry weight of the stem (41.44 and 45.54 $\mathrm{g} / \mathrm{plant}$ ) in the first and second seasons, respectively. These values were significantly higher than those of the control plants, or plants receiving any other humic acid concentration. Increases in the dry weight of stems as a result of humic acid treatments have been reported by Hussein (2009) on Cryptostegia grandiflora.

Regarding the interaction between the effects of irrigation with a line water salinity and humic acid treatments, the results recorded in the two seasons show that the heaviest stem dry weights of 48.20 and $52.52 \mathrm{~g}$ per plant in the first and second seasons, respectively) were those of plants irrigated with tap water and sprayed with humic acid at $1000 \mathrm{ppm}$. On the other hand, the lowest stem dry weights (28.23 and 32.16 g per plant in the first and second seasons, respectively) were obtained in the plants irrigated with the highest salt concentrations (9000 ppm) without humic acid treatment. These results are in agreement with the findings of Aslam et al. (2002) on Eucalyptus camaldulensis, Franklin et al. (2002) on Pinus banksiana, Gupta et al. (2002) on Ziziphus rotundifolia and Ziziphus nummularia, El-Feky (2004) on Erythrina indica and Tecoma stans, and Abd El-Aziz et al. (2006) on Khaya senegalensis.

\subsubsection{Root length $(\mathrm{cm})$}

Data presented in Table (2c) show that all the tested irrigation water treatments significantly decreased the root length $(\mathrm{cm})$ of Jatropha curcas, compared to that of plants irrigated with tap water (control). In both seasons, plants irrigated with tap water had the highest mean root length 38.58 and $42.12 \mathrm{~cm}$ in the first and second seasons, respectively. Raising the salt concentration caused a steady reduction in the root length, which reached its lowest values 27.12 and $31.08 \mathrm{~cm}$ in the first and second seasons, respectively, in plants irrigated using the highest salt concentration (9000 ppm). Similar results were reported by El-Feky (2004) on Erythrina indica and Tecoma stans and Abd El-Aziz et al. (2006) on Khaya senegalensis.

The data in Table (2c) also indicate that humic acid treatments had a significant effect on the root length. As with the other vegetative growth parameters, spraying the plants with humic acid at $1000 \mathrm{ppm}$ gave the tallest root length 34.93 and $38.54 \mathrm{~cm}$ in the first and second seasons, respectively. A similar increase in the fresh weight of roots as a result of humic acid treatments was recorded by Ashish et al. (2010) on Jatropha curcas.

Regarding the interaction between the effects of irrigation water and humic acid treatments on root length of Jatropha curcas plants, the results recorded in the two seasons showed that, the highest values were obtained in plants irrigated with tap water and sprayed with humic acid at 1000 ppm (with mean length of 41.00 and 44.08 $\mathrm{cm}$ in the first and second seasons, respectively). On the other hand, the shortest roots (with mean length of 23.58 and $27.00 \mathrm{~cm}$ in the first and second seasons, respectively) were those irrigated using the highest salt concentration (9000 ppm) without humic acid treatment. It can also be seen from the data presented in Table (2c) that in many cases, spraying the plants with humic acid reduced the undesirable effect of salinity.

\subsubsection{Root dry weight (g)}

Data presented in Table (2c) show that irrigation of Jatropha curcas plants with saline water significantly decreased the dry weights of roots, compared to the plants irrigated with tap water (control). In both seasons, plants irrigated with tap water had the heaviest dry weight of roots 42.44 and $46.16 \mathrm{gm} /$ plant in the first and second seasons, respectively. Steady significant reductions in the dry weight of roots were recorded as the salt concentration in the irrigation water was increased, with the highest salt concentration $(9000 \mathrm{ppm})$ giving the least mean values in both seasons 30.03 and 34.12 $\mathrm{gm} /$ plant in the first and second seasons, respectively.

Regarding the effect of humic acid treatments on the dry weight of roots, data in Table (2c) show that spraying Jatropha curcas plants with humic acid at $1000 \mathrm{ppm}$ significantly increased the recorded values, compared to the control. The highest dry roots 38.48 and $42.54 \mathrm{gm} /$ plant in the first and second seasons, respectively, were those of plants sprayed with humic acid at $1000 \mathrm{ppm}$. A similar increase in the dry weight of roots was recorded by Zaghloul et al. (2009) on Thuja orientalis, El-Khateeb et al. (2010) on Calia secundiflora and Cavalcante et al. (2011) on Carica papaya.

Regarding the interaction between the effects 
Table (2c): Means of vegetative growth characteristics of Jatropha curcas plants as influenced by Salinity (S), Humic acid (HA) and their combinations $(\mathrm{S} \times \mathrm{HA})$ in the two seasons of 2012 and 2013.

\begin{tabular}{|c|c|c|c|c|c|}
\hline \multicolumn{2}{|c|}{ Treatments } & \multicolumn{2}{|c|}{ Root length (cm) } & \multicolumn{2}{|c|}{ Root dry weight (g) } \\
\hline $\begin{array}{c}\text { Salinity } \\
\text { (ppm) }\end{array}$ & $\begin{array}{c}\text { Humic acid } \\
\text { (ppm) }\end{array}$ & 2012 & 2013 & 2012 & 2013 \\
\hline \multirow{4}{*}{0} & 0 & 35.00 & 39.08 & 38.52 & 42.99 \\
\hline & 500 & 39.33 & 42.91 & 43.28 & 46.56 \\
\hline & 1000 & 41.00 & 44.08 & 45.10 & 48.34 \\
\hline & 1500 & 39.00 & 42.41 & 42.88 & 46.76 \\
\hline \multicolumn{2}{|l|}{ Mean } & 38.58 & 42.12 & 42.44 & 46.16 \\
\hline \multirow{4}{*}{3000} & 0 & 30.25 & 33.75 & 33.62 & 37.27 \\
\hline & 500 & 34.00 & 37.16 & 37.46 & 40.89 \\
\hline & 1000 & 36.50 & 40.08 & 40.13 & 44.10 \\
\hline & 1500 & 33.25 & 36.75 & 36.66 & 41.16 \\
\hline \multicolumn{2}{|l|}{ Mean } & 33.50 & 36.93 & 36.97 & 40.85 \\
\hline \multirow{4}{*}{6000} & 0 & 27.25 & 30.75 & 29.99 & 34.55 \\
\hline & 500 & 31.00 & 34.41 & 34.32 & 37.82 \\
\hline & 1000 & 32.75 & 36.33 & 36.02 & 39.97 \\
\hline & 1500 & 31.00 & 34.58 & 34.36 & 38.22 \\
\hline \multicolumn{2}{|l|}{ Mean } & 30.50 & 34.02 & 33.67 & 37.64 \\
\hline \multirow{4}{*}{9000} & 0 & 23.58 & 27.00 & 25.95 & 29.71 \\
\hline & 500 & 27.16 & 31.25 & 29.92 & 33.86 \\
\hline & 1000 & 29.50 & 33.66 & 32.66 & 36.94 \\
\hline & 1500 & 28.25 & 32.41 & 31.59 & 36.00 \\
\hline \multicolumn{2}{|l|}{ Mean } & 27.12 & 31.08 & 30.03 & 34.12 \\
\hline \multirow{4}{*}{ Mean (HA) } & 0 & 29.02 & 32.64 & 32.02 & 36.13 \\
\hline & 500 & 32.87 & 36.43 & 36.24 & 39.78 \\
\hline & 1000 & 34.93 & 38.54 & 38.48 & 42.54 \\
\hline & 1500 & 32.87 & 36.54 & 36.37 & 40.53 \\
\hline \multirow{3}{*}{ L.S.D. at 0.05} & $\mathbf{S}$ & 1.76 & 1.49 & 1.92 & 1.57 \\
\hline & H A & 0.66 & 0.54 & 0.79 & 0.59 \\
\hline & $\mathbf{S} \times \mathbf{H A}$ & 2.09 & 1.75 & 2.34 & 1.86 \\
\hline
\end{tabular}

of irrigation water and humic acid treatments, the data presented in Table (2c) show that the highest values (45.10 and $48.34 \mathrm{~g}$ per plant in the first and second seasons, respectively) were obtained in plants irrigated with tap water and sprayed with humic acid at $1000 \mathrm{ppm}$. On the other hand, the lowest dry weight of roots $(25.95$ and $29.71 \mathrm{~g}$ per plant in the first and second seasons, respectively) were obtained from plants irrigated using the highest salt concentration (9000 ppm), with no humic acid treatment. Similar results were reported by Sayed (2006) on Ficus alii.

\subsection{Chemical constituents}

\subsubsection{Chlorophyll content (SPAD unites)}

The results presented in Table (3a) show that the highest content of total chlorophyll was obtained in plant irrigation with tap water 54.85 and 55.12 SPAD in the first and second seasons, respectively. Raising the salt concentration in irrigation water resulted in steady significant reductions in the total chlorophyll content, which reached its lowest value 49.50 and 50.01 SPAD in the first and second seasons, respectively, in plants receiving the highest salt concentration $9000 \mathrm{ppm}$. The decrease in the total chlorophyll content as a result of raising the salt concentration in irrigation water is in agreement with the results reported by El-Feky (2004) on Erythrina indica and Tecoma stans, and Helmy (2004) on Senna occidentalis.

The results of leaf chemical analysis (Table 3a) also show that the tested humic acid treatments had a clear effect on the total 
Table (3a): Means of chemical constituents characteristics of Jatropha curcas plants as influenced by salinity (S), humic acid (HA) and their combinations $(\mathrm{S} \times \mathrm{HA})$ in the two seasons of 2012 and 2013.

\begin{tabular}{|c|c|c|c|c|c|c|c|}
\hline \multicolumn{2}{|c|}{ Treatments } & \multicolumn{2}{|c|}{$\begin{array}{l}\text { Chlorophyll content } \\
\text { (SPAD unites) }\end{array}$} & \multicolumn{2}{|c|}{$\begin{array}{c}\text { Carbohydrates } \\
\text { content }(\%)\end{array}$} & \multicolumn{2}{|c|}{$\begin{array}{c}\text { Proline content } \\
(\mathrm{mg} / \mathrm{g})\end{array}$} \\
\hline $\begin{array}{c}\text { Salinity } \\
\text { (ppm) }\end{array}$ & $\begin{array}{l}\text { Humic acid } \\
\quad(\mathbf{p p m})\end{array}$ & 2012 & 2013 & 2012 & 2013 & 2012 & 2013 \\
\hline \multirow{4}{*}{0} & 0 & 52.55 & 52.99 & 19.50 & 20.21 & 1.34 & 1.37 \\
\hline & 500 & 53.94 & 54.36 & 20.84 & 20.74 & 1.29 & 1.32 \\
\hline & 1000 & 57.32 & 57.42 & 21.86 & 21.90 & 1.25 & 1.29 \\
\hline & 1500 & 55.62 & 55.71 & 21.21 & 21.25 & 1.15 & 1.20 \\
\hline \multicolumn{2}{|l|}{ Mean } & 54.85 & 55.12 & 20.85 & 21.02 & 1.26 & 1.29 \\
\hline \multirow{4}{*}{3000} & 0 & 48.37 & 49.13 & 18.45 & 18.73 & 1.87 & 1.88 \\
\hline & 500 & 50.47 & 50.57 & 19.25 & 19.28 & 1.75 & 1.79 \\
\hline & 1000 & 56.89 & 56.99 & 21.20 & 21.46 & 1.71 & 1.74 \\
\hline & 1500 & 55.09 & 55.51 & 20.72 & 21.15 & 1.71 & 1.74 \\
\hline \multicolumn{2}{|l|}{ Mean } & 52.70 & 53.05 & 19.90 & 20.16 & 1.76 & 1.78 \\
\hline \multirow{4}{*}{6000} & 0 & 47.31 & 48.08 & 18.04 & 18.33 & 2.24 & 2.28 \\
\hline & 500 & 50.03 & 50.12 & 18.81 & 19.12 & 2.16 & 2.22 \\
\hline & 1000 & 54.43 & 54.53 & 20.23 & 19.72 & 2.12 & 2.17 \\
\hline & 1500 & 53.49 & 53.59 & 19.61 & 20.43 & 2.14 & 2.18 \\
\hline \multicolumn{2}{|l|}{ Mean } & 51.31 & $\begin{array}{l}51.58 \\
\end{array}$ & 19.17 & 19.40 & 2.16 & 2.21 \\
\hline \multirow{4}{*}{9000} & 0 & 45.44 & 46.54 & 17.33 & 17.74 & 2.50 & 2.48 \\
\hline & 500 & 49.72 & 50.14 & 18.70 & 19.11 & 2.40 & 2.39 \\
\hline & 1000 & 52.21 & 52.31 & 19.92 & 19.94 & 2.39 & 2.36 \\
\hline & 1500 & 50.62 & 51.04 & 19.04 & 19.45 & 2.40 & 2.35 \\
\hline \multicolumn{2}{|l|}{ Mean } & 49.50 & 50.01 & 18.75 & 19.06 & 2.42 & 2.39 \\
\hline \multirow{4}{*}{ Mean (HA) } & 0 & 48.42 & 49.18 & 18.33 & 18.75 & 1.99 & 2.00 \\
\hline & 500 & 51.04 & 51.30 & 19.40 & 19.56 & 1.90 & 1.93 \\
\hline & 1000 & 55.21 & 55.31 & 20.80 & 20.75 & 1.86 & 1.89 \\
\hline & 1500 & 53.70 & 53.96 & 20.15 & 20.57 & 1.85 & 1.87 \\
\hline \multirow{3}{*}{ L.S.D. at 0.05} & $\mathbf{S}$ & 1.01 & 1.16 & 0.69 & 0.46 & 0.05 & 0.04 \\
\hline & HA & 0.66 & 0.62 & $\begin{array}{l}0.42 \\
\end{array}$ & 0.29 & 0.02 & 0.02 \\
\hline & $\mathbf{S} \times \mathbf{H A}$ & 1.51 & 1.65 & $\begin{array}{ll}1.01 \\
\end{array}$ & 0.67 & 0.05 & 0.04 \\
\hline
\end{tabular}

chlorophyll content. The recorded mean values ranged from 55.21 and 55.31 SPAD in the first and second seasons, respectively, in plants sprayed with humic acid at $1000 \mathrm{ppm}$ to 48.42 and 49.18 SPAD in the first and second seasons, respectively, in plants sprayed with humic acid at $0 \mathrm{ppm}$. Similar results were reported by Tejada and Gonzalez (2003) on asparagus and Ferrara et al. (2008) on grape.

Regarding to the interaction between the effects of saline irrigation water and humic acid treatments, the data presented in Table (3a) showed that the highest total chlorophyll contents of 57.32 and 57.42 in the first and second seasons, respectively, were found in the the leaves of plants irrigated with tap water and sprayed with humic acid at $1000 \mathrm{ppm}$, the lowest values of 45.44 and 46.54 in the first and second seasons, respectively, were obtained in plants irrigated with saline water at $9000 \mathrm{ppm}$ and sprayed with tap water. The decrease in the total chlorophyll content as a result of raising the salt concentration in irrigation water is in agreement with the results reported by El-Feky (2004) on Erythrina indica and Tecoma stans, and Helmy (2004) on Senna occidentalis.

\subsubsection{Carbohydrate contents (\%)}

The data resulting from leaf chemical analysis in Table (3a) show that, the total carbohydrates \% in the dried leaves of Jatropha curcas plants decreased steadily with raising the salt concentration in the irrigation water. The 
highest mean carbohydrate content 20.85 and $21.02 \%$ in the first and second seasons, respectively, was found in the leaves of the control plants, whereas the lowest mean value 18.75 and $19.06 \%$ in the first and second seasons, respectively, was found in the plants irrigated with water containing the highest salt concentration $9000 \mathrm{ppm}$. Decreases in the carbohydrate \% with increasing the salinity level have been reported by El-Feky (2004) on Erytherina indica and Tecoma stans. The reduction in the carbohydrate content in leaves of the plants irrigated using saline water may be attributed to the reduction in the total chlorophyll content as a result of the salinity treatments (as previously mentioned). This reduction in the chlorophyll content leads to a reduction in the rate of photosynthesis which occurs within the leaf tissues, leading in turn to a reduction in the synthesis and accumulation of carbohydrates.

The results in (Table 3a) also show that most of the tested humic acid concentrations increased the mean total carbohydrates \% in the leaves of Jatropha curcas plants, compared to the control. Among the plants receiving the different humic acid treatments, plants sprayed with $1000 \mathrm{ppm}$ humic acid had the highest carbohydrate $\%$ in leaves 20.80 and $20.75 \%$ in the first and second seasons, respectively. Increases in the carbohydrates \% in the leaves of plants receiving humic acid treatments have also been reported by Hussein (2009) on Cryptostegia grandiflora.

Concerning the interaction between the effects of saline irrigation water and humic acid treatments on the carbohydrate contents $\%$ of leaves, the results presented in Table (3a) show that the highest mean values of 21.86 and 21.90 $\%$ in the first and second seasons, respectively, were obtained in the leaves of plants irrigated with tap water and sprayed with humic acid at $1000 \mathrm{ppm}$. On the other hand, the lowest carbohydrate content was obtained in the leaves of plants irrigated with saline water at $9000 \mathrm{ppm}$ and receiving no humic acid treatment.

\subsubsection{Proline content $(\mathrm{mg} / \mathrm{g})$}

Results of leaf samples taken from plants receiving different irrigation water treatments (Table 3a) show that, with increasing the level of salinity in water, the proline contents $(\mathrm{mg} / \mathrm{g})$ in dry leaves generally increased. Accordingly, plants irrigated with the highest salt concentration (9000 ppm) had the highest mean proline value 2.42 and $2.39 \mathrm{mg} / \mathrm{g}$ in the first and second seasons, respectively. On the other hand, plants irrigated with tap water had the lowest mean proline value 1.26 and $1.29 \mathrm{mg} / \mathrm{g}$ in the first and second seasons, respectively. Similar results were reported by Kumar et al. (2003) on Morus alba, and Woodward and Bennett (2005) on Eucalyptus camaldulensis. The considerable enhancement of proline accumulation in plants irrigated using high salt concentrations may lead to the conclusion that proline plays a role in plant tolerance to salinity. This role was explained by Greenway and Munns (1980), who mentioned that proline can be considered as a stabilizer of osmotic pressure within the cell. Also, Maraim (1990) and Marcum and Murdoch (1994) concluded that proline can make a substantial contribution to cytoplasmic osmotic adjustment.

As for the effect of different combinations of saline irrigation water and humic acid concentrations, it is clear from data in Table (3a) that considerable differences in the proline $(\mathrm{mg} / \mathrm{g})$ were detected in the leaves of plants receiving the different combinations of water salinity and humic acid treatments. The highest mean values of 2.50 and $2.48 \mathrm{mg} / \mathrm{g}$ dry matter in the first and second seasons, respectively, were obtained in plants irrigated with saline water at 9000 ppm, and receiving no humic acid treatment. On the other hand, the least proline values 1.15 and $1.20 \mathrm{mg} / \mathrm{g}$ dry matter in the first and second seasons, respectively, were obtained from plants irrigated with tap water and sprayed with humic acid at $1500 \mathrm{ppm}$. Similar results were reported by Campos et al. (2012) on Jatropha curcas.

\subsubsection{Relative Water Content of leaves (\%)}

Results of leaf samples taken from plants receiving different irrigation water treatments (Table $3 b$ ) show that, with increasing the level of salinity in water, the relative water content $\%$ in fresh leaves was generally decreased. Accordingly, plants irrigated with the highest salt concentration (9000 ppm) had the lowest mean relative water content value 57.93 and $56.00 \%$ in the first and second seasons, respectively. On the other hand, plants irrigated with tap water had the highest mean relative water content value 83.49 and $76.61 \%$ in the first and second seasons, respectively. The considerable enhancement of relative water content accumulation in plants irrigated using high salt concentrations may lead to the conclusion that relative water content plays a role in plant tolerance to salinity. This role was explained by Greenway and Munns (1980), who 
Table (3b): Means of chemical constituents characteristics of Jatropha curcas plants as influence by salinity (S), humic acid (HA) and their combinations $(\mathrm{S} \times \mathrm{HA})$ in the two seasor of 2012 and 2013.

\begin{tabular}{|c|c|c|c|c|c|c|c|}
\hline \multicolumn{2}{|c|}{ Treatments } & \multicolumn{2}{|c|}{$\begin{array}{c}\text { Relative Water } \\
\text { Content }(\%) \text { of leaves }\end{array}$} & \multicolumn{2}{|c|}{$\begin{array}{c}\text { Sodium content } \\
(\% \text { D.W. of leaves })\end{array}$} & \multicolumn{2}{|c|}{$\begin{array}{l}\text { Chloride content } \\
\text { (\% D.W. of leaves) }\end{array}$} \\
\hline $\begin{array}{l}\text { Salinity } \\
\text { (ppm) }\end{array}$ & $\begin{array}{l}\text { Humic acid } \\
\text { (ppm) }\end{array}$ & 2012 & 2013 & 2012 & 2013 & 2012 & 2013 \\
\hline \multirow{4}{*}{0} & 0 & 77.96 & 74.96 & 0.50 & 0.50 & 0.38 & 0.39 \\
\hline & 500 & 84.50 & 76.50 & 0.40 & 0.41 & 0.30 & 0.31 \\
\hline & 1000 & 87.05 & 78.64 & 0.34 & 0.33 & 0.26 & 0.25 \\
\hline & 1500 & 84.43 & 76.34 & 0.28 & 0.25 & 0.20 & 0.19 \\
\hline \multicolumn{2}{|l|}{ Mean } & 83.49 & 76.61 & 0.38 & 0.37 & 0.28 & 0.28 \\
\hline \multirow{4}{*}{3000} & 0 & 74.12 & 70.58 & 1.21 & 1.25 & 0.96 & 0.99 \\
\hline & 500 & 75.15 & 72.54 & 1.18 & 1.18 & 0.93 & 0.94 \\
\hline & 1000 & 77.32 & 73.98 & 1.11 & 1.12 & 0.88 & 0.89 \\
\hline & 1500 & 74.13 & 71.66 & 1.01 & 1.04 & 0.80 & 0.83 \\
\hline \multicolumn{2}{|l|}{ Mean } & 75.18 & 72.19 & 1.13 & 1.15 & 0.89 & 0.91 \\
\hline \multirow{4}{*}{6000} & 0 & 64.64 & 62.27 & 1.77 & 1.82 & 1.41 & 1.45 \\
\hline & 500 & 67.19 & 63.73 & 1.66 & 1.68 & 1.32 & 1.34 \\
\hline & 1000 & 67.81 & 66.05 & 1.45 & 1.46 & 1.15 & 1.17 \\
\hline & 1500 & 65.82 & 63.57 & 1.49 & 1.51 & 1.18 & 1.20 \\
\hline \multicolumn{2}{|l|}{ Mean } & 66.37 & 63.90 & 1.59 & 1.62 & 1.26 & 1.29 \\
\hline \multirow{4}{*}{9000} & 0 & 56.25 & 53.79 & 2.09 & 2.09 & 1.68 & 1.68 \\
\hline & 500 & 58.26 & 56.39 & 1.92 & 1.96 & 1.53 & 1.57 \\
\hline & 1000 & 59.10 & 57.87 & 1.83 & 1.87 & 1.46 & 1.49 \\
\hline & 1500 & 58.12 & 55.97 & 1.71 & 1.76 & 1.36 & 1.40 \\
\hline \multicolumn{2}{|l|}{ Mean } & 57.93 & 56.00 & 1.89 & 1.92 & 1.50 & 1.53 \\
\hline \multirow{4}{*}{ Mean (HA) } & 0 & 68.24 & 65.40 & 1.39 & 1.41 & 1.10 & 1.12 \\
\hline & 500 & 71.28 & 67.29 & 1.29 & 1.31 & 1.02 & 1.04 \\
\hline & 1000 & 72.82 & 69.13 & 1.18 & 1.19 & 0.39 & 0.95 \\
\hline & 1500 & 70.62 & 66.88 & 1.12 & 1.14 & 0.88 & 0.90 \\
\hline \multirow{3}{*}{$\begin{array}{l}\text { L.S.D. at } \\
0.05\end{array}$} & $\mathbf{S}$ & 2.17 & 0.71 & 0.06 & 0.03 & 0.02 & 0.01 \\
\hline & HA & 0.56 & 0.47 & 0.04 & 0.01 & 0.01 & 0.01 \\
\hline & $\mathbf{S} \times \mathbf{H A}$ & 2.37 & 1.08 & 0.08 & 0.03 & 0.02 & 0.01 \\
\hline
\end{tabular}

mentioned that relative water content can be considered as a stabilizer of osmotic pressure within the cell.

As for the effect of different combinations of saline irrigation water and humic acid concentrations, it is clear from data in Table (3b) that considerable differences in the relative water content $(\%)$ were detected in the leaves of plants receiving the different combinations of water salinity and humic acid treatments. The highest mean values 87.05 and $78.64 \%$ in the first and second seasons, respectively, were obtained in plants irrigated with tap water, and receiving humic acid at $1000 \mathrm{ppm}$. On the other hand, the lowest relative water contents 56.25 and $53.79 \%$ in the first and second seasons, respectively, were obtained from plants irrigated with saline water $(9000 \mathrm{ppm})$ and sprayed without humic acid. Similar results were reported by Sapeta et al. (2013) on Jatropha curcas.

\subsubsection{Sodium percentage in leaves $(\%)$}

The results presented in Table ( $3 b$ ) show that the $\mathrm{Na} \%$ in the dried leaves of Jatropha curcas plants was increased steadily with raising the salt concentration in the irrigation water. Accordingly, the lowest $\mathrm{Na}$ content 0.38 and $0.37 \%$ in the first and second seasons, respectively, was found in leaves of the control plants, whereas the highest content 1.89 and 1.92 $\%$ in the first and second seasons, respectively, was found in the plants irrigated with water 
containing the highest salt concentration 9000 ppm. Increases in the $\mathrm{Na}$ contents with increasing the salinity level have been reported by Franklin et al. (2002) on Pinus banksiana, ElFeky (2004) on Erytherina indica and Tecoma stans, and Cassanitia et al. (2009) on ornamental shrubs.

The results in Table (3b) also show that the mean $\mathrm{Na} \%$ content of the leaves was slightly reduced by spraying the plants with $1500 \mathrm{ppm}$ humic acid which gave a sodium content of 1.12 and $1.14 \%$ in the first and second seasons, respectively, compared to the control. The highest value (1.39 and $1.41 \%$ in the first and second seasons, respectively) was recorded in plants sprayed with humic acid at $0 \mathrm{ppm}$ (control).

Regarding the interaction between the effects of saline irrigation water and humic acid concentrations on the $\mathrm{Na} \%$ of the leaves, the data presented in Table (3b) show that the highest values 2.09 and $2.09 \%$ in the first and second seasons, respectively, were obtained from plants irrigated with saline water at 9000 ppm and sprayed without humic acid. On the other hand, the lowest values 0.28 and $0.25 \%$ in the first and second seasons, respectively, were obtained from plants irrigated with tap water and sprayed with humic acid at $1500 \mathrm{ppm}$ treatment. Increases in the $\mathrm{Na}$ contents with increasing the salinity level have been reported by Franklin et al. (2002) on Pinus banksiana, El-Feky (2004) on Erytherina indica and Tecoma stans, and Cassanitia et al. (2009) on a number of ornamental shrubs.

\subsubsection{Chloride percentage in leaves $(\%)$}

From the data presented in Table (3b), it can be seen that the chloride $\%$ in the dried leaves of Jatropha curcas plants increased steadily with raising the salt concentration in the irrigation water. Accordingly, the least $\mathrm{Cl}^{-}$value $(0.28$ and $0.28 \%$ in the first and second seasons, respectively) was found in the control plants, whereas the highest value $(0.64$ and $0.65 \%$ in the first and second seasons, respectively) was found in plants irrigated with water containing high salt concentration 9000 ppm. Similar increases in the leaf $\mathrm{Cl}^{-}$contents with increasing the salinity level were reported by Helmy (2004) on Senna occidentalis, and Cassanitia et al. (2009) on ornamental shrubs.

The results in Table (3b) also show that the mean leaf $\mathrm{Cl}^{-} \%$ was reduced steadily with raising humic acid concentration. Accordingly, the highest $\mathrm{Cl}^{-}$value $(0.47$ and $0.48 \%$ in the first and second seasons, respectively) was recorded in the leaves of control plants, whereas plants sprayed with the highest humic acid concentration $1500 \mathrm{ppm}$ had the lowest $\mathrm{Cl}^{-}$value ( 0.38 and $0.39 \%$ in the first and second seasons, respectively).

Regarding the interaction between the effect of saline irrigation water and humic acid concentrations on the $\mathrm{Cl} \%$, the data in Table (3b) show that the highest mean values 1.68 and $1.68 \%$ in the first and second seasons, respectively, were obtained in plants irrigated with saline water at $9000 \mathrm{ppm}$ and sprayed with tap water, while the lowest mean values 0.20 and $0.19 \%$ in the first and second seasons, respectively, were recorded in plants irrigated with tap water and sprayed with humic acid at $1500 \mathrm{ppm}$. Similar increases in the $\mathrm{Cl}^{-}$contents with increasing the salinity level were reported by Helmy (2004) on Senna occidentalis, Cassanitia et al. (2009) on a number of ornamental shrubs.

\section{Conclusions}

The results about the vegetative growth parameters and chemical compositions of Jatropha curcas showed that spraying with humic acid at $1000 \mathrm{ppm}$ and the irrigation with tap water (control) gave the highest significant values of vegetative growth and chemical parameters . It can also notice that spraying the plants with humic acid reduced the undesirable effect of salinity level (not more 6000ppm concentrate) of lower quality water (water of reimage). Moreover, in some cases, the humic acid treatments helped to overcome the adverse effect of the salinity treatments on stem thickening.

\section{REFERENCES}

Abd El-Aziz N. G., Mazher A. A. M. and Habba E. (2006). Effect of foliar spraying with ascorbic acid on growth and chemical constituents of Khaya senegalensis grown under salt condition. American - Eurasian J. Agri. \& Environ. Sci., 1(3): 207 - 214.

Ashish D. P., Nilesh S. P., Indu B. P. and Amar N. P. (2010). Growth, water status and nutrient accumulation of seedlings of Jatropha curcas L. (Euphorbiaceae) in response to soil salinity. Anales de Biologia 32: 59-71.

Aslam Z., Awan A. R., Qureshi M. A. A., Mahmood T., Haq M. I., Chaudhry A. K. and Malik K. A. (2002). Growth, ion 
uptake, agro-industrial uses and environmental implications of Eucalyptus camaldulensis in saline systems. Prospects for Saline Agriculture. Kluwer Academic Publishers, pp. $277-285$.

Awan M. F., Siddiqui T. I., Khan R. A. and Shah A. H. (2002a). Combined effect of salinity and industrial effluents on the growth of Eucalyptus camaldulensis Dehnh. Pak. J. Agric. Sci., 39(2): 80-82.

Awan M. F., Siddiqui T. I., Khan R. A. and Shah A. H. (2002b). Interaction of salinity and industrial effluents on the growth of Dalbergia sissoo (Shisham) seedlings. Int'l J. Agric. and Biol., 4(2): 240-241.

Barrs D. (1968). Determination of water deficits in plant tissues.. In: Water deficits and plant growth. T.T. Kozlowski (ed.). Vol.1 pp. 235 - 368 Academic Press, London ,UK.

Bates L.S., Waldern R.P. and Teare L. D. (1973). Rapid determination of free proline under water stress studies. Plant and Soil, 39: 205-207.

Campos M., Hsie B.S., Granja J.A., Correia R.M., Cortez J.S., and Pompelli M.F. (2012). Photosynthesis and antioxidant activity in Jatropha curcas L. under salt stress. Brazilian Soc. Plant Physiol., 24(1): 55-67.

Cassanitia C., Leonardia C. and Flowers T. J. (2009). The effect of sodium chloride on ornamental shrubs. Scientia Horticulturae, 122(4): 586-593.

Cavalcante H. L., Da Silva R. S., Albano F. G., De Lima F. N. and Marques A. Des. (2011). Foliar spray of humic substances on seedling production of papaya (Pawpaw). J. Agron., 10(4): 118-122.

Dubios M., Gilles K., Hamlton J., Rebers P., and Smith F.(1956). Colourimetric method for determination of sugars and related substances. Analytical Chem. 28 (3): 350356.

El-Bagoury H., Hossni Y. A., El-Tantawy A., Shehata M. and Asmael R. (1999). Effect of saline water in irrigation on growth and chemical composition of Casuarina equisetifolia L. seedling. Egypt. J. Hort., 26: 47-57.

El-Feky A. E. A. M. (2004). Respone of Erythrina indica and Tecoma stans plants to some treatments. Ph.D. Thesis, Fac. Agric., Cairo Univ., Egypt, 186p.
EI-Juhany L. and Aref L. M. (2005). Interactive effects of low water supply and high salt concentration on the growth and dry matter partitioning of Conocarpus erectus seedlings. Saudi J. Biol. Sci., 12(2): 147157.

El-Juhany L., Aref L. M. and Ahmed A. T. M. (2008). Response of Eucalyptus camaldulensis, Eucalyptus intertexta and Eucalyptus microtheca seedlings to irrigation with saline water. World of Agric. Sci., 4(5): 825 - 834 .

El-Khateeb M. A., Nasr A. A., Fahmy A. N. and Dorgham A. H. (2010). Effect of $\mathrm{GA}_{3}$ and growth biostimulants on growth and chemical composition of Calia secundiflora plants. J. Hort. Sci. \& Ornamen. Plants., 2(2): 118-124.

Fathy M. A., Gabr M. A. and El-Shall S. A. (2010). Effect of humic acid treatments on "Canino" apricot growth, yield and fruit quality. New York Sci. J., 3(12): 109-115.

Ferrara G., Pacifico A., Simeone P. and Ferrara E. (2008). Preliminary study on the effects of foliar application of humic acid on "Italia" table grape. J. Int'l des Sci. de la Vigne et du Vin, 42(2): 79-87.

Franklin J. A., Zwiazek J. J., Renault S. and Croser C. (2002). Growth and elemental composition of jack pine (Pinus banksiana) seedlings treated with sodium chloride and sodium sulfate. Trees Structure and Function, 16(4/5): 325 330.

Genhua N., Denise R., Mike M., John J. and Girisha G. (2012). Responses of Jatropha curcas to salt and drought stresses. Int., J. Agron., (2012), Article ID 632026: 1-7.

Greenway H. and Munns R. (1980). Mechanisms of salt tolerance in non-halophytes. Ann. Rev. of Plant Physiol., 31: 149-190.

Gu-Zuliang, Chen-Hong, Zhong-Qilin, ChenChang Cai and Tang-Huanqing (2002). Effect of application of bio-organic manure: Guomanduo for Navel Orange. South China Fruits, 31 (4): 26.

Gupta N. P., Meena S. K., Gupta S. and Khandelwal (2002). Gas exchange, membrane permeability, and ion uptake in two species of Indian jujube differing in salt tolerance. Photosynthetica, 40(4): 535 $-539$.

Helmy S. S. (2004). Effect of irrigation intervals and salt concentrations on the growth and chemical composition of Senna 
occidentalis L. Link. M.Sc. Thesis, Fac. Agric., Cairo Univ., Egypt, 135 p.

Hussein M. M. (2009). Effect of gibberellic acid and chemical fertilization on growth and chemical composition of Cryptostegia grandiflora. J. hort. Sci. \& Ornamental Plants, 1(2):27-38.

Jackson N. L. (1958). Soil Chemical Analysis. Constable. Ltd. Co., London, UK.498 p.

Janick J. and Rebort E. P. (2008). The Encyclopedia of Fruit \& Nuts (http://books.google.com/books?id=cjHC OMQNKcgC). CABI. pp: 371-372.

Juhasz A.C.P., Pimenta S., Soares B., Soares O., de Lourdes B.M., Rabella D. and de Oliveira H. (2009). Floral biology and artificial polinization in physic nut in the North of Minas Gerais State, Brazil. Pesquisa Agropecuaria Brasileira, 44(9): 1073-1077.

Kumar S., Reddy A. A. and Sudhakar C. (2003). $\mathrm{NaCl}$ effects on proline metabolism in two high yielding genotyps of mulberry (Morus alba L.) with contrasting salt tolerance. Plant Sci., 165(6): 1245-1251.

Maraim K. B. (1990). Physiological parameters of salinity tolerance in $\mathrm{C}_{4}$ turfgrasses. Dissertation Abstracts International. B: Sciences and Engineering, 51 (5): $484 \mathrm{~B}$. (C.f. Hort. Abst., 61: 10274).

Marcum K. B. and Murdoch C. L. (1994). Salinity tolerance mechanisms of six $\mathrm{C}_{4}$ turfgrasses. J. Amer. Soc. Hort. Sci., 119 (4): 779-784.

Piper C.S. (1947). Soil and Plant Analysis. The Univ. of Adelaide, Australia, pp. 258274.

Ritche J. J. (1974). Atmospheric and soil water influences on the plant water balance. Agric. Meth. 14: 1993 - 1998.

Sapeta H., Miguel C., Tiago L., Joao M., Piet L., Margarida O. (2013). Drought stress response in Jatropha curcas: Growth and physiology. Environ. and Experi. Bot., 85: $76-84$.

Sayed A. B. F. (2006). Physiological studies on Ficus alii plants. M.Sc. Thesis, Fac. Agric., Cairo Univ., Egypt.

Sharif F. and Khan A. U. (2009). Alleviation of salinity tolerance by fertilization in four thorn forest species for the reclamation of salt-affected sites. Pak. J. Bot., 41(6): 2901-2915.

Snedecor G. and Cochran W. (1974). Statistical Methods. Sixth Edition. Iowa State University Press. Ames. Iowa. USA.

St. Arnaud M. and Vincent G. (1990). Influence of high salt levels on the germination and growth of five potentially utilizable plants for median turfmg in northern climates. J. Environ. Hort., 6(4): 118-121. (C.f. Hort. Abst., 61, 10052).

Tejada M. and Gonzalez J. L. (2003). Influence of foliar fertilization with amino acids and humic acids on productivity and quality of asparagus. Biol. Agric. Hort., 21:277-291.

Woodward A. J. and Bennett I. J. (2005). The effect of salt stress and abscisic acid on proline production, chlorophyll content and growth of in vitro propagated shoots of Eucalyptus camaldulensis. PL. C., T. and O. C., 82: 189-200.

Yadava U. (1986). A rapid and non destructive method to determine chlorophyll in intact leaves. Hort. Sci., 21(6): 1449-1450.

Yasseen B. T., Mohammed H. A. and Soliman E. D. (1987). Growth of prophyll, and proline accumulation due to salt stress in three barley cultivars. Iraqi J. Agric. Sci., 5(2): 155-166. (C. f. Field Crop Abst., 40: 5633).

Zaghloul S. M., El-Quesni F. E. M. and Mazhar A.A.M. (2009). Infiuence of potassium humate on growth and chemical constituents of Thuja Orientalis L seedling. Ozean J. Appl. Sci., 2(1): 73-78. 


\section{تأثير معاملات الملوحة وحمض الهيوميك على النمو والتركيب الكيميائى لنباتات الجاتروفا \\ نادر أحمد الثنهورى - محمد زيدان سالم* ـ نشوى حسن محمد}

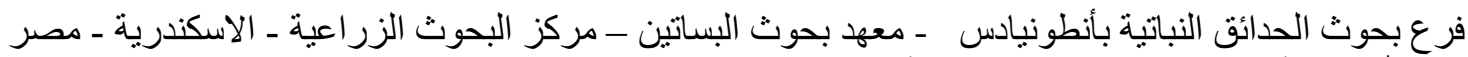

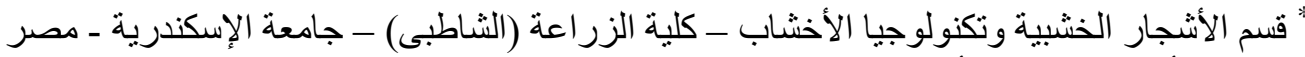

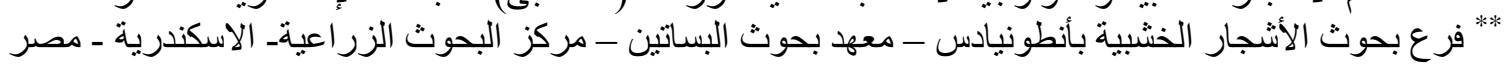

\section{ملخص}

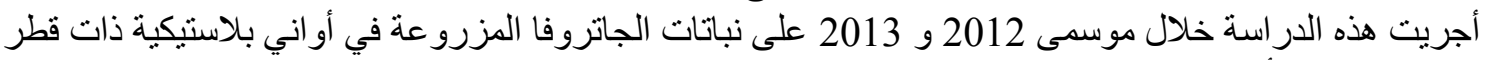

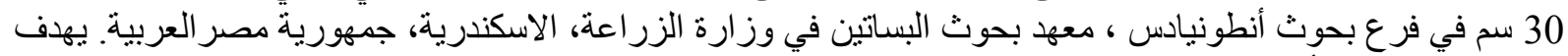

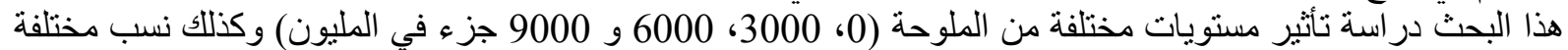

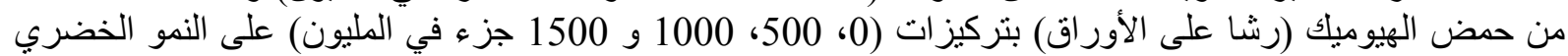

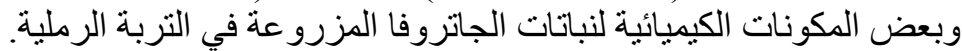

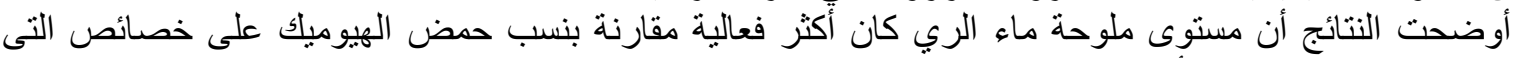

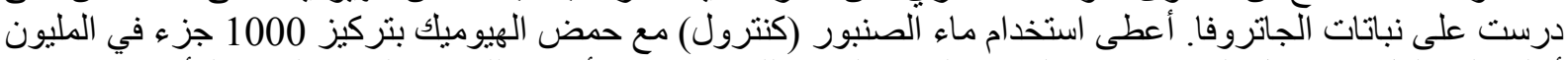

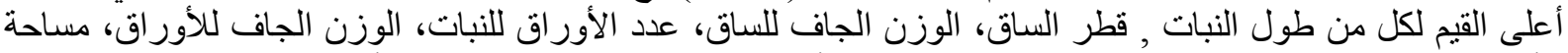

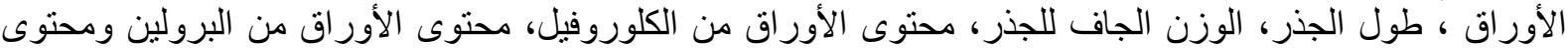

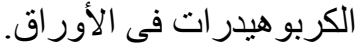

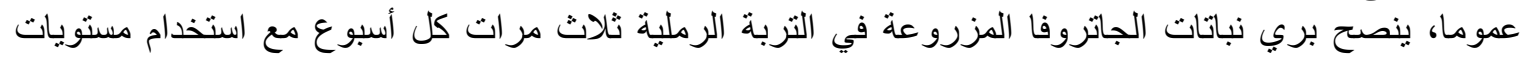

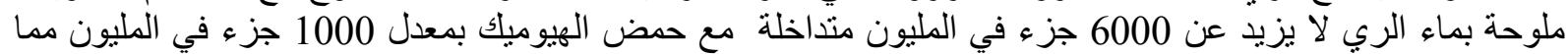

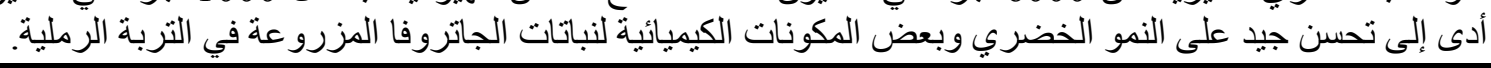

المجلة العلمية لكلية الزراعة - جامعة القاهرة - المجلا (65) العلد الرابع (أكتوبر 2014) 474-488. 